\title{
Junk and Fast Food Consumption among Obese University Students
}

Hafiza Hina Nawaz ${ }^{1}$, Sana Farooq ${ }^{2}$, Bahisht Rizwan ${ }^{2}$, Sana Noreen $^{2 *}$, Saira Azhar ${ }^{3}$, Huseen Bukht ${ }^{2}$, Amsa Fatima $^{2}$, Anum Ashraf $^{2}$, Fatima Abid $^{2}$

${ }^{1}$ Student, University Institute of Diet and Nutritional Sciences, the University of Lahore, Punjab, Pakistan

${ }^{2}$ Senior Lecturer, Faculty of Allied Health Sciences, University Institute of Diet and Nutritional Science, the University of Lahore, Pakistan

${ }^{3}$ Lecturer, Allied Health Sciences, Rashid Latif Medical College, Pakistan

Article History

Received: 13.10 .2020

Accepted: 24.10 .2020

Published: 30.10 .2020

Journal homepage:

https://www.easpublisher.com/easjnfs

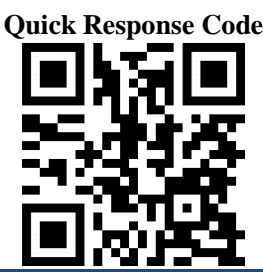

Abstract: Inadequate nutrition awareness and many other risk factors contribute to severe disorders or diseases. Nowadays, individuals are more concerned about better taste and presentation than health. Advertisements and peer pressure play a vital role, and also other factors lead to many diseases related to obesity. The study was conducted to evaluate the fast-food consumption and factors influencing fast food consumption; moreover, to assess health complications related to obesity among university students suffering from obesity. A cross-sectional study was conducted at Fatima Memorial College of Medicine and Dentistry, and The University of Lahore, Lahore, over four months. A total number of 200 adolescent females were selected through a non-probability convenient sampling technique. Data were collected through a self-structured questionnaire. SPSS version 21.0 was used. Out of 200 students, $56 \%$ of students preferred to eat fast food over healthy food while $44 \%$ of students did not prefer. Moreover, $63 \%$ of students consumed fast food daily. $37 \%$ of students ate healthy food, $57 \%$ of students consume junk food daily, $43 \%$ of students preferred to eat junk food daily, while $57 \%$ of students liked sugary food daily.

Keywords: Fast food, junk food, consumption, obesity, overweight, students.

Copyright (C) 2020 The Author(s): This is an open-access article distributed under the terms of the Creative Commons Attribution 4.0 International License (CC BY-NC 4.0) which permits unrestricted use, distribution, and reproduction in any medium for non-commercial use provided the original author and source are credited.

\section{INTRODUCTION}

According to the World Health Organization, overweight for adults is considered as holding a BMI of $\geq 25$. In contrast, obesity is considered to be holding a BMI of $\geq 30$ [1]. Obesity is a metabolic disorder all over the world. It is one of the main leading causes of death, as it is known to be a threat to the increased incidence of various non-transmittable illnesses, specifically type 2 diabetes [2].

Obesity is a primary risk factor for dyslipidemia development, featuring the way that the more significant part of people with diabetes is overweight or obese [3]. Until today the BMI is as yet used to group overweight and determination. Since decreased mainstream is remarkably pervasive all through the BMI range, the estimation of the body part is recommended [4]. Now Pakistan has been considered at the sixth largest country in the world, and by 2050, it is predictable to be the fourth-largest, according to evaluations by the United Nation (UN) [5].

\section{MATERIAL AND METHODS}

A cross-sectional study was done on students from Fatima Memorial College of medicine and dentistry, and The University of Lahore, from
November 2018 to February 2019. A total of 200 obese adolescent females aged 17-25 years were selected for this study. Data were analysed with the help of SPSS version 21.0.

\section{RESULTS}

Table-1: Socio-demographic profile of the Participants

\begin{tabular}{|c|c|c|}
\hline Sr. No. & Socio-demographic Data & Percentage (\%) \\
\hline 1. & Geographical Location \\
\hline & Urban & $90 \%$ \\
\hline & Rural & $10 \%$ \\
\hline 2. & Socioeconomic status \\
\hline & Lower class & $5 \%$ \\
\hline & Middle Class & $84 \%$ \\
\hline & High class & $11 \%$ \\
\hline 3. & Residential status \\
\hline & \multicolumn{2}{|c|}{ Own } \\
\hline & \multicolumn{2}{|c|}{ Rented } \\
\hline 4. & \multicolumn{2}{|c|}{ Overweight (25-29.9) } \\
\hline & Obesity grade1 (35-39.9) & $73 \%$ \\
\hline & Obesity grade2 (40-44.9) & $1 \%$ \\
\hline
\end{tabular}

According to table 1, out of 200 students, $90 \%$ were living in urban areas, while $10 \%$ were living in 
rural areas; almost $5 \%$ of students belonged to the lower class family. $84 \%$ belonged to the middle-class family, while only $11 \%$ of students belonged to the high-class family. $74 \%$ of students had their own houses while only $26 \%$ of students were living in a rented house. Moreover, according to BMI, $73 \%$ of students were overweight, $26 \%$ had obesity grade 1 , while only $1 \%$ of students had obesity grade 2 .

Table-2: Junk and Fast Food Consumption

\begin{tabular}{|c|c|c|c|}
\hline Sr. No. & Junk food and Fast Food Consump & ion & Percentage (\%) \\
\hline \multirow[t]{2}{*}{1.} & \multirow[t]{2}{*}{ Preference for fast food/junk food over healthy food } & Yes & $56 \%$ \\
\hline & & No & $44 \%$ \\
\hline \multirow[t]{2}{*}{2.} & \multirow[t]{2}{*}{ Consumption of fast food per day } & Yes & $63 \%$ \\
\hline & & No & $37 \%$ \\
\hline \multirow[t]{2}{*}{3} & \multirow[t]{2}{*}{ Consumption of junk food per day } & Yes & $57 \%$ \\
\hline & & No & $43 \%$ \\
\hline \multirow[t]{2}{*}{4.} & \multirow[t]{2}{*}{ Sugary food consumption per day } & Yes & $57 \%$ \\
\hline & & No & $43 \%$ \\
\hline \multirow[t]{2}{*}{5.} & \multirow[t]{2}{*}{ Fatty food consumption } & Yes & $72 \%$ \\
\hline & & No & $28 \%$ \\
\hline \multirow[t]{4}{*}{6.} & \multirow[t]{4}{*}{ Timings of consumption } & Before 12 pm & $8 \%$ \\
\hline & & Between 12-4 pm & $37 \%$ \\
\hline & & Between 4-8 pm & $37 \%$ \\
\hline & & $10 \mathrm{pm}$ or late hours & $18 \%$ \\
\hline \multirow[t]{2}{*}{7.} & \multirow[t]{2}{*}{ Place of consumption } & Eat home & $44 \%$ \\
\hline & & Dine-out & $56 \%$ \\
\hline
\end{tabular}

According to table 2, out of 200 students, $56 \%$ student preferred to eat junk and fast foods over healthy foods, while $44 \%$ of students did not prefer. Moreover, $63 \%$ of students consumed fast food daily, while $37 \%$ of students did not consume fast food daily. $57 \%$ of students consumed junk food daily, while $43 \%$ of students did not consume junk food daily. 57\% of students liked to eat sugary foods daily, wheres, $43 \%$ did not like to eat sugary foods daily. $72 \%$ of students consumed fatty food daily, while only $28 \%$ of students did not prefer to eat fatty food daily. Furthermore, only $8 \%$ students consumed the food before $12 \mathrm{pm}, 37 \%$ students consumed the food between 12 to $4 \mathrm{pm}$, while $37 \%$ students consumed the food between 4 to $8 \mathrm{pm}$ and $18 \%$ students consume the food $10 \mathrm{pm}$ or late hours. Additionally, $44 \%$ of students preferred to eat at home, while $56 \%$ of students preferred to dine-out.

Table-3: Influencing factors with fast food and junk food consumption

\begin{tabular}{|c|c|c|c|}
\hline Sr. No. & \multicolumn{2}{|c|}{ Factors Influencing Junk food and Fast Food Consumption } & Percentage (\%) \\
\hline \multirow[t]{2}{*}{1.} & \multirow[t]{2}{*}{ Eating during stress } & Yes & $57 \%$ \\
\hline & & No & $43 \%$ \\
\hline \multirow[t]{2}{*}{2.} & \multirow[t]{2}{*}{ Eating oily foods due to cravings during stress } & Yes & $48 \%$ \\
\hline & & No & $52 \%$ \\
\hline \multirow[t]{2}{*}{3.} & \multirow[t]{2}{*}{ Eating out } & Yes & $69 \%$ \\
\hline & & No & $31 \%$ \\
\hline \multirow[t]{2}{*}{4.} & \multirow[t]{2}{*}{ Eating snacks while using a laptop } & Yes & $70 \%$ \\
\hline & & No & $30 \%$ \\
\hline \multirow[t]{2}{*}{5.} & \multirow[t]{2}{*}{ Fizzy/Soft drinks } & Yes & $75 \%$ \\
\hline & & No & $25 \%$ \\
\hline \multirow[t]{2}{*}{6.} & \multirow[t]{2}{*}{ Less nutrition education } & Yes & $69 \%$ \\
\hline & & No & $31 \%$ \\
\hline \multirow[t]{3}{*}{7.} & \multirow[t]{3}{*}{ Travelling time on bus or car } & 2 hour & $32 \%$ \\
\hline & & 3 hours & $42 \%$ \\
\hline & & $\geq 3$ hours & $26 \%$ \\
\hline \multirow[t]{2}{*}{8.} & \multirow[t]{2}{*}{ Physically Activity } & Yes & $41 \%$ \\
\hline & & No & $59 \%$ \\
\hline \multirow[t]{3}{*}{9.} & \multirow[t]{3}{*}{ Watching TV } & 1 hour & $38 \%$ \\
\hline & & 2 hours & $35 \%$ \\
\hline & & $\geq 3$ hours & $27 \%$ \\
\hline
\end{tabular}

According to the table 3, out of 200 students $57 \%$ students liked to eat junk food and fast food during stress while $43 \%$ students did not like to eat junk food and fast food during stress. $48 \%$ of students ate oily foods due to cravings during stress, while $52 \%$ of students did not eat oily foods due to cravings during stress. Moreover, $69 \%$ of students preferred to eat-out. In comparison, only $31 \%$ of students did not like to eat out. $70 \%$ of students ate snacks while using a laptop; however, $30 \%$ students did not eat snacks while using 
the laptop. 38\% students used to watch TV for just 1 hour in a day while $35 \%$ students watched TV for 2 hours in a day and $27 \%$ students watched TV for more than 3 hours in a day; $32 \%$ students were travelling for just 2 hours in a day, $42 \%$ students were travelling for 3 hours in a day while $26 \%$ were travelling for more than 3 hours in a day. $41 \%$ of students were physically active while $59 \%$ of students were not physically active. $75 \%$ of students liked to drink the fizzy drink with food, while only $25 \%$ of students did not like to drink the fizzy drink with food intake. Moreover, $69 \%$ of students were less aware of nutrition education while $31 \%$ of students had nutrition information.

\begin{tabular}{|c|c|c|c|}
\hline & \multicolumn{2}{|l|}{$\begin{array}{c}\text { Health Issues } \\
\end{array}$} & Percentage $(\%)$ \\
\hline \multirow[t]{2}{*}{1.} & \multirow{2}{*}{ Hypercholesterolemia } & Yes & 55 \\
\hline & & No & 45 \\
\hline \multirow{2}{*}{2.} & \multirow[t]{2}{*}{ Hypertensive } & Yes & 66 \\
\hline & & No & 34 \\
\hline \multirow[t]{2}{*}{3.} & \multirow[t]{2}{*}{ Diabetes } & Yes & 35 \\
\hline & & No & 65 \\
\hline \multirow[t]{2}{*}{4.} & \multirow[t]{2}{*}{ CVD } & Yes & 29 \\
\hline & & No & 71 \\
\hline
\end{tabular}

According to table 4, out of 200 students, 55\% of students were suffering from hypercholesterolemia, while $45 \%$ of students had normal cholesterol levels. $66 \%$ of students were hypertensive, while $34 \%$ of students were not hypertensive. $35 \%$ were diabetic, while $65 \%$ of students were non-diabetic, $27 \%$ of students had heart disease. In contrast, $71 \%$ did not have any sort of heart issue.

\section{DISCUSSION}

The study was directed to find out the junk and fast food consumption among university students suffering from obesity of age between 17-25 years. Students were selected through non-probability sampling technique. The results of the current data showed that the majority liked to consume sugary foods. A similar study indicated that high consumption of sugar and carbohydrate consumption in the diet caused obesity [6].

Additionally, the present study showed that $75 \%$ of students consumed fizzy drinks. A study showed that high energy carbonated drinks consumption leads to obesity, osteoporosis and weak bones [7]. Likewise, a study in 2014, showed that consumption of soft drinks was strongly associated with obesity [7]. According to the study, the students were obese or overweight, and $59 \%$ of students were physically inactive. A similar study was done to evaluate the link between physical activity, watching sports on television and the harmful effects of obesity in teenagers. On average participants reported watching TV for four to five hours a day and the study showed an association between less physical activity and high risk of Obesity [8]. The current study showed that the students were spending their time in travelling by bus or car for more than two hours daily. Moreover, a study was conducted, in 2008, which showed that the use of transportation instead of walking for every purpose was one of the major factors that increased the risk of obesity [9].
The current study showed that students preferred to eat snacks as fast/junk foods. Driskell et al., [10] also recorded similar results while conducting a study to evaluate the frequency of eating meals and snacks as fast foods available at restaurants, and factors inducing on food choices. According to the report, almost $84 \%$ of men and $58 \%$ of women were consuming fast food for lunch at least once a week [10]. Moreover, the results of the current study showed that the students consumed high fatty foods daily. A study indicated the adverse effects on endothelial functions due to the consumption of fatty foods; it also caused health problems like CVD and high cholesterol [11]. Moreover, the current study showed that the majority of university students frequently dinned out. A similar study showed a positive association between take-away food consumption and high BMI among students [12].

The results of the current studies showed that majority of the students were not aware of the nutrition education. Likewise, a study performed in 2012 suggested that insufficient nutrition education promotes weight gain and obesity among adults $[13,14]$.

\section{CONCLUSION}

Conclusively, there was a high consumption rate of fast food and junk food among obese and overweight students. Moreover, fast/junk food consumption and obesity were being affected by stress, screen time, travelling time, physical activity, food cravings, and dining out. Less nutrition information among students was also contributing to the inadequate intake of a healthy diet among the students, resulting in increased BMI.

\section{REFERENCES}

1. Abarca-Gómez, L., Abdeen, Z.A., Hamid, Z.A., Abu-Rmeileh, N.M., Acosta-Cazares, B., Acuin, C., Adams, R.J., Aekplakorn, W., Afsana, K., 
Aguilar-Salinas, C.A., \& Agyemang, C. (2017). Worldwide trends in body-mass index, underweight, overweight, and obesity from 1975 to 2016: a pooled analysis of 2416 population-based measurement studies in 128. 9 million children, adolescents, and adults. The Lancet, 390(10113), 2627-2642.

2. Raza, Q., Doak, C. M., Khan, A., Nicolaou, M., \& Seidell, J. C. (2013). Obesity and cardiovascular disease risk factors among the indigenous and immigrant Pakistani population: a systematic review. Obesity facts, 6(6), 523-535.

3. Stein, C. J., \& Colditz, G. A. (2004). The epidemic of obesity. The Journal of Clinical Endocrinology \& Metabolism, 89(6), 2522-2525.

4. Yumuk, V., Tsigos, C., Fried, M., Schindler, K., Busetto, L., Micic, D., \& Toplak, H. (2015). European guidelines for obesity management in adults. Obesity facts, 8(6), 402-424.

5. Kim, D. M., Ahn, C. W., \& Nam, S. Y. (2005). Prevalence of obesity in Korea. Obesity Reviews, 6(2), 117-121.

6. Bowman, S. A., \& Vinyard, B. T. (2004). Fast food consumption of US adults: impact on energy and nutrient intakes and overweight status. Journal of the american college of nutrition, 23(2), 163-168.

7. Paeratakul, S., Ferdinand, D. P., Champagne, C. M., Ryan, D. H., \& Bray, G. A. (2003). Fast-food consumption among US adults and children: dietary and nutrient intake profile. Journal of the American dietetic Association, 103(10), 1332-1338.

8. Hamer, M., Weiler, R., \& Stamatakis, E. (2014). Watching sport on television, physical activity, and risk of obesity in older adults. BMC Public Health, 14(1), 1-4.

9. Bassett, D. R., Pucher, J., Buehler, R., Thompson, D. L., \& Crouter, S. E. (2008). Walking, cycling, and obesity rates in Europe, North America, and Australia.Journal of physical activity and health, 5(6), 795-814.

10. Driskell, J. A., Meckna, B. R., \& Scales, N. E. (2006). Differences exist in the eating habits of university men and women at fast-food restaurants. Nutrition research, 26(10), 524-530.

11. Rudolph, T. K., Ruempler, K., Schwedhelm, E., Tan-Andresen, J., Riederer, U., Böger, R. H., \& Maas, R. (2007). Acute effects of various fast-food meals on vascular function and cardiovascular disease risk markers: the Hamburg Burger Trial. The American journal of clinical nutrition, 86(2), 334-340.

12. Burgoine, T., Forouhi, N. G., Griffin, S. J., Wareham, N. J., \& Monsivais, P. (2014). Associations between exposure to takeaway food outlets, takeaway food consumption, and body weight in Cambridgeshire, UK: population based, cross sectional study. Bmj, 348, g1464.

13. Bibeau, W. S., Saksvig, B. I., Gittelsohn, J., Williams, S., Jones, L., \& Young, D. R. (2012). Perceptions of the food marketing environment among African American teen girls and adults. Appetite, 58(1), 396-399.

14. Kirkpatrick, S. I., Reedy, J., Kahle, L. L., Harris, J. L., Ohri-Vachaspati, P., \& Krebs-Smith, S. M. (2014). Fast-food menu offerings vary in dietary quality, but are consistently poor. Public health nutrition, 17(4), 924-931. 